\title{
(1) Current Situation and Solutions to Advanced Ventilation Efficiency in Giap Khau Coal Mine Area, Hon Gai Coal Company of Viet Nam
}

\author{
Nguyen CAO KHAI ${ }^{1, \star)}$, Nguyen VAN THINH ${ }^{1)}$, Nguyen PHI HUNG ${ }^{1)}$, \\ Dao VAN CHI ${ }^{1)}$, Nguyen VAN QUANG ${ }^{1)}$
}

\footnotetext{
${ }^{1)}$ Department of Underground Mining, Hanoi University of Mining and Geology, 18 Vien street, Hanoi, Vietnam; email: nguyencaokhai@humg.edu.vn; nguyenvanthinhhl@humg.edu.vn; nguyenphihung@humg.edu.vn; daovanchi@humg.edu.vn; nguyenvanquang@humg.edu.vn
}

\section{http://doi.org/10.29227/IM-2020-02-26}

Submission date: 06-03-2020 | Review date: 22-09-2020

\section{Abstract}

Mine ventilation aims to dilute toxic gas concentrations, dilute dust concentrations, remove them from the mine and ensure pleasant microclimate conditions in the mine, especially at work sites. Currently, in underground coal mines in general and in Giap Khau mine area, Hon Gai coal company, in particular, is in the process of converting the mining area into deep, as well as increasing output. Therefore, it is important to ensure that ventilation is a top priority in long-term occupational safety and meets the plan to increase coal production. In this study, we have evaluated the current state of ventilation in Giap Khau mine area. From those research results, on the basis of computational research methods, we have come up with reasonable solutions to change and improve ventilation efficiency for the mine in the condition of complicated mining plan and technology characteristics are still limited compared to those in the world. Specific solutions solve 2 problems: First, ensure ventilation for the current mining operation stage; Secondly, we have researched and proposing suitable solutions for ventilation of Giap Khau area mine when it has to increase production and move down to an adjacent project at a deeper level.

Keywords: mine ventilation, mine safety ventilation, GiapKhau mines area

\section{Introduction}

Giap Khau coal mine is an underground coal mining Hon Gai Coal Company; currently, the mine is implement mining project to surface to -50 and incorporating lower-level project development -50. The output of Giap Khau mine in 2019 is 300000 tons/year (Hon Gai coal Company - Vietnam, 2019b); Vietnam coal - minerals industries holding corporation limited, 2019a).

The current mining area is at level +20 to level -50 with the need to mobilize 03 long-walls into operation. Regarding the preparation, the moderate production area of the mine combined with the basic construction work to open the mining area deep down, so the mining area must have 10 digging tunnel lines simultaneously (Hon Gai coal Company - Vietnam, 2019a; Hon Gai coal Company - Vietnam, 2019b).

Currently, due to the fact that the area of exploitation has not been deep and the mine output is still low, the ventilation situation is still favourable. However, when additional longwalls are used, or the lower level project is put into operation, the ventilation system will be changed. Therefore, it is necessary to study for appropriate orientation solutions for future mine ventilation.

2. Assessment of the current status of mine ventilation 2.1. Specification of the mine ventilation system in 2019

The mine is ventilated by suction ventilation method, with 03 fan stations which are FBDCZ-4-No13/2x22kW fans (each fan station has an additional backup fan) and placed at three different tunnel doors (Hon Gai coal Company - Vietnam, 2019a).
Current status of a regional wind network diagram is structured from the kiln lines tunnel, with three operating longwalls and 10 digging tunnels. Overall this is a relatively simple wind network. The mine consists of 4 seams: V8, V11, V12 and V13. The schematic diagram of the ventilation tunnel system is shown in Fig. 1 (Nguyen Cao Khai et al., 2019):

\subsection{Ventilation calculation for area mine}

a. To calculate ventilation for Giap Khau area, we apply the formula later (Tran Xuan Ha et al.., 2014; Babak G.A, K.P. Bocharov, AT Volokhiev, 1982):

$\mathrm{Q}_{\mathrm{m}}=1.1\left(\mathrm{k}_{\mathrm{sl}} . \Sigma \mathrm{Q}_{\mathrm{kt}}+\Sigma \mathrm{Q}_{\mathrm{cb}}+\Sigma \mathrm{Q}_{\mathrm{ht}}+\Sigma \mathrm{Q}_{\mathrm{rg}}\right) ; \mathrm{m}^{3} / \mathrm{s}$

Inside:

1.1 - The coefficient refers to the uneven distribution of wind in wind currents.

$\mathrm{k}_{\mathrm{sl}}$ - Coefficients to account for the increase in output of the longwall (select $\mathrm{kt}=1.1$ ).

$\Sigma Q_{\mathrm{rg}}$ - Total leakage airflow in mine, $\mathrm{m} 3 / \mathrm{s}$.

$\Sigma Q_{\mathrm{lc}}$ - Total amount of airflow required for the longwall face, $\mathrm{m}^{3} / \mathrm{s}$.

$\Sigma \mathrm{Q}_{\mathrm{cb}}$ - Total amount of airflow needed for the roadway heading or heading, $\mathrm{m}^{3} / \mathrm{s}$.

$\Sigma \mathrm{Q}_{\mathrm{ht}}$ - Total amount of airflow required for the station, $\mathrm{m}^{3} / \mathrm{s}$.

The results of the calculation of airflow for the mine are as follows:

$\mathrm{Q}_{\mathrm{m}}=1.1(1.1 \times 9.73+23.0+3.9+5.04)=46.9 \mathrm{~m}^{3} / \mathrm{s}$ 


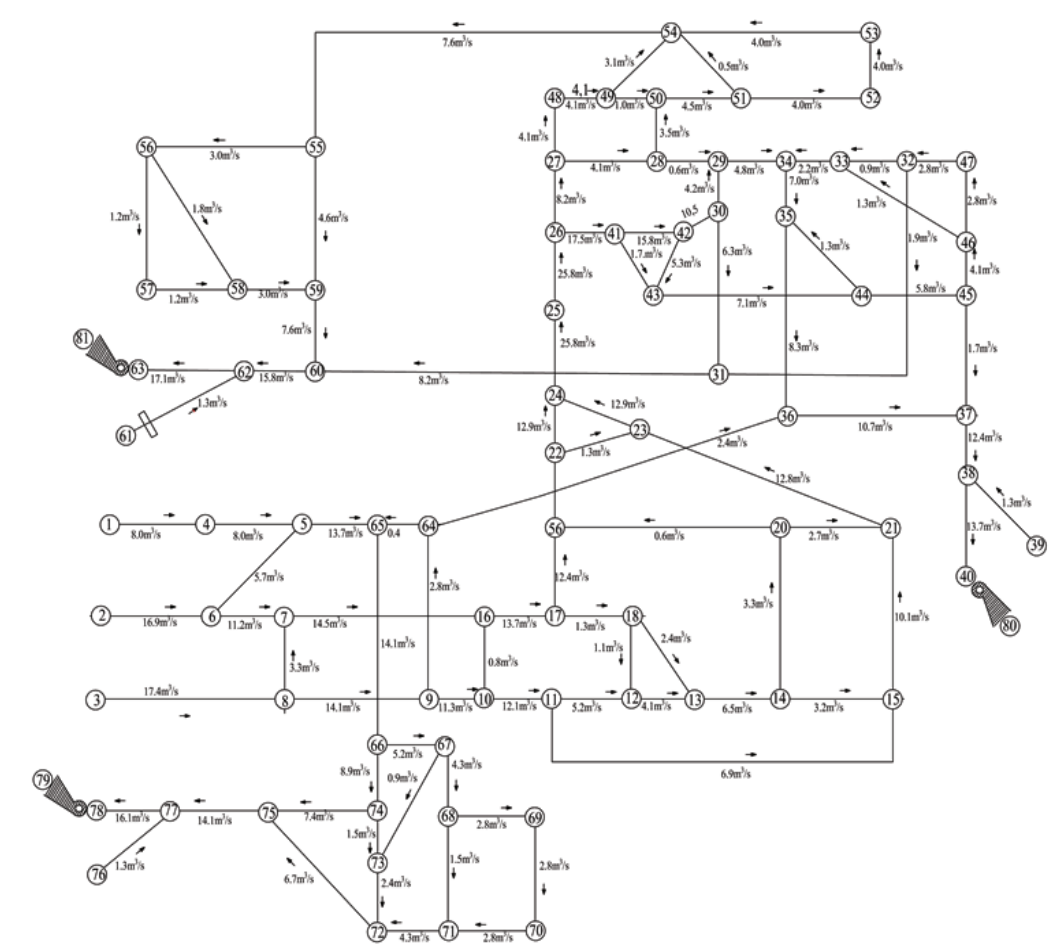

Fig. 1. Ventilation diagram of Giap Khau area mine Rys. 1. Schemat wentylacji kopalni Giap Khau

Giap Khau mines area is ventilated by 03 fan stations located at the three doors of tunnels: Level +36 ; Level +45 and +29 is the fan type FBDCZ-4-No13/2x22kW. So we have to calculate the airflow for 03 fan stations to take charge, to determine the working mode of 03 main fans above. On the basis of wind consumers, the wind-wind network system, we distribute the corresponding wind to the wind branches undertaken by three fans. Results of airflow calculation for branches for fans are as follows (Nguyen Cao Khai et al., 2019):

- Fan 1 (+36: FBDCZ-4-No13/2x22kW): Qm1 = $17.1 \mathrm{~m}^{3} / \mathrm{s}$;

- Fan 2 (Level +45: FBDCZ-4-No13/2x22kW): Qm2 = 16.1 $\mathrm{m}^{3} / \mathrm{s}$;

- Fan 3 (Level +130: FBDCZ-4-No13/2x22kW): Qm3 = 13.1 $\mathrm{m}^{3} / \mathrm{s}$;

b. Calculation mine ventilation pressure

To Calculation mine ventilation pressure, we calculate the low pressure of the wind currents and apply the formula (Tran Xuan Ha et al., 2014; Babak G.A, K.P. Bocharov, AT Volokhiev, 1982):

$$
h_{m}=\sum h_{m s}+\sum h_{c b}, m m H_{2} O
$$

In which:

$\Sigma_{\text {hms }}$ : The total hypotension is caused by the frictional resistance of the segments that follow each other in airflow, calculated from the beginning to the endpoint. This pressure lowering is calculated according to the formula (Tran Xuan Ha, Nguyen Cao Khai et al.., 2014):

$$
h_{m s}=\alpha_{i} \frac{L_{i} \cdot P_{i}}{S_{i}^{3}} \cdot Q_{i}^{2} ; \mathrm{mm} \mathrm{H} 2 \mathrm{O}
$$

In which: $\alpha_{i}$ : The aerodynamic resistance coefficient in the ith tunnel on the airflow, $\mathrm{kGS} 2 / \mathrm{m}^{4}$;

$\mathrm{L}_{\mathrm{i}}, \mathrm{P}_{\mathrm{i}}, \mathrm{S}_{\mathrm{i}}$ : Length, circumference, the cross-section of the tunnel i;

$\mathrm{Q}_{\mathrm{i}}$ : The amount of wind going through the ith tunnel, $\mathrm{m}^{3} / \mathrm{s}$. $\Sigma_{\mathrm{hCb}}$ : The total hypotension due to local resistance calculated by an airflow, in fact, is often taken from (10-25\%) hms.

The results of ventilation pressure of the following lines (Nguyen Cao Khai et al., 2019):

$$
\begin{aligned}
-\mathrm{hm}_{1} & =95,51 \mathrm{mmH}_{2} \mathrm{O} . \\
-\mathrm{hm}_{2} & =80,33 \mathrm{mmH}_{2} \mathrm{O} . \\
-\mathrm{hm}_{5} & =69,8 \mathrm{mmH}_{2} \mathrm{O} .
\end{aligned}
$$

c. Optimal working mode of the main fans

The calculation to determine the working mode of the main fans is calculated based on the general regulations and using the calculation method to determine the working mode of the fans by the graph method (Nguyen Cao Khai et al., 2015). The result of determining the working mode of main fans is as follows:

- Fan station No.1: Door of tunnel the level +36 , the reasonable working point of the fan is Actl as shown in Fig. 2. With parameters:

$$
\begin{aligned}
& \mathrm{Q}_{\mathrm{ct} 1}=20.9 \mathrm{~m}^{3} / \mathrm{s} ; \\
& \mathrm{h}_{\mathrm{ct} 1}=131.9 \mathrm{mmH}_{2} \mathrm{O} ; \\
& \mathrm{n}=740 \mathrm{r} / \mathrm{m} ; \\
& \theta=00 ; \\
& \eta_{1}=0.81 .
\end{aligned}
$$

- Fan station No.2: Door of tunnel the level +45 , the reasonable working point of the fan is Act1 as shown in Fig. 3. With parameters: 


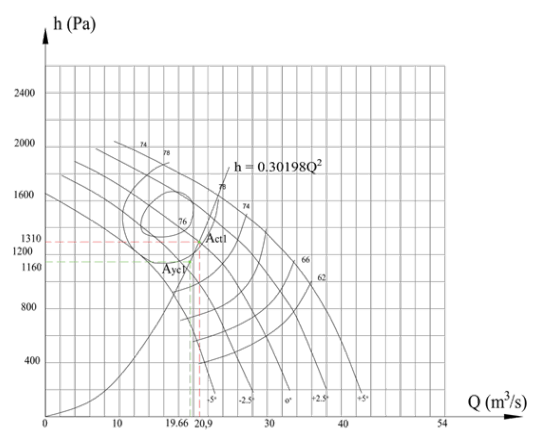

Fig. 2. Graph of determining the working mode of the fan FBDCZ-4-No13 at the door of tunnel the level +36 Rys. 2. Wykres określania trybu pracy wentylatora FBDCZ-4-No13 na wejściu do tunelu na poziomie +36

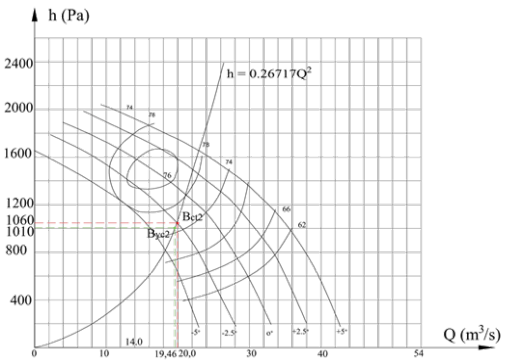

Fig. 3. Graph of determining the working mode of the fan FBDCZ-4-No13 at the door of tunnel the level +45 Rys. 3. Wykres określania trybu pracy wentylatora FBDCZ-4-No13 na wejściu do tunelu na poziomie +45

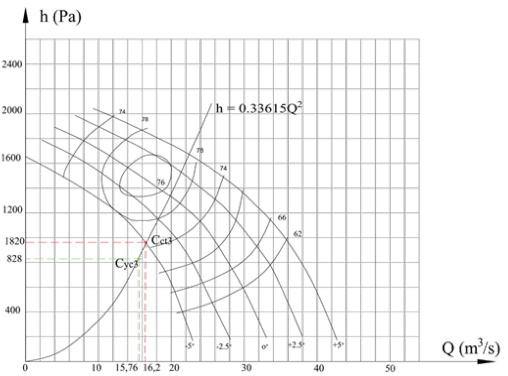

Fig. 4. Graph of determining the working mode of the fan FBDCZ-4-No13 at the door of tunnel the level +130 Rys. 4. Wykres określania trybu pracy wentylatora FBDCZ-4-No13 na wejściu do tunelu na poziomie +130

$\mathrm{Q}_{\mathrm{ct} 1}=20.0 \mathrm{~m} 3 / \mathrm{s}$;

$\mathrm{h}_{\mathrm{ct} 1}=106.8 \mathrm{mmH} 2 \mathrm{O}$;

$\mathrm{n}=740 \mathrm{r} / \mathrm{m}$;

$\theta=-2.50$;

$\eta_{1}=0.78$.

- Fan station No.3: Door of tunnel the level +130 , the reasonable working point of the fan is Actl as shown in Fig. 4. With parameters:

$\mathrm{Q}_{\mathrm{ct} 1}=16.2 \mathrm{~m}^{3} / \mathrm{s}$

$\mathrm{h}_{\mathrm{ct} 1}=88.2 \mathrm{mmH}_{2} \mathrm{O}$;

$\mathrm{n}=740 \mathrm{r} / \mathrm{m}$;

$\theta=-50$;

$\eta_{1}=0.74$.

a. General assessment of mining ventilation network

- Ventilation method: Giap Khau field, ranked I in terms of methane, open mines with pairs of inclined wells combined with tunnel faces of different levels: With pairs of inclined wells (Main well from level +32 to level -188 ; Secondary well from $+32 /-160)$ and Underground conveyor from level +30 to level -50. The wells serve the task of bringing clean wind, transporting coal and materials, so the mine uses suction ventilation method to ventilate the mine is perfectly reasonable.

The mine is ventilated by suction ventilation method, thanks to the use of three main fans which are fan type with fan code FBDCZ-4-No13/2x22kW) located at the ventilated doors tunnels levels: $+36 ;+45$ and +130 . The fans are made by China. Fan station location is presented on the drawing of the Fig.1.

- Regarding the ventilation diagram and the quality of the tunnels lines: In general, the diagram of the ventilation network of the mine is relatively simple. In this diagram: Clean wind passes through the main wells, auxiliary wells, conveyor underground, through the crossroads, along with the transportation levels and into the ventilation for mining market faces and construction faces by Local fans (YBT-42-2, YBT52-2, YBT-62-2, DBKJ-N6, FBDY-N6, FBD-N6) combine with the duct. The exhaust air from the longwall through the tunnel along the level ventilation flats of the longwall faces, through the upper ventilation, through the tunnel along the ventilation seams, then drained out through 3 main fans: set at +36 ; set at +45 and set at +130 . 
Tab. 1. Results of actual airflow through long-walls

Tab. 1. Wyniki rzeczywistego przepływu powietrza przez ściany

\begin{tabular}{|c|l|c|c|c|c|c|}
\hline \multirow{2}{*}{ No } & \multicolumn{2}{|c|}{ Longwall name } & \multicolumn{2}{|c|}{ Airflow parameters $\left.\mathrm{m}^{3} / \mathrm{s}\right)$} & \multicolumn{3}{|c|}{ Evaluate } \\
\cline { 3 - 7 } & & Necessary & Reality & Excess $\left(\mathrm{m}^{3} / \mathrm{s}\right)$ & Deficient $\left(\mathrm{m}^{3} / \mathrm{s}\right)$ & Note \\
\hline 1 & Longwall level -40/-35 V8 & 5.0 & 5.4 & 0.4 & - & Satisfactory \\
\hline 2 & Longwall level -10 V13 & 3.2 & 3.25 & 0.05 & - & Satisfactory \\
\hline 3 & Longwall level -20 V13 & 3.2 & 3.25 & 0,05 & - & Satisfactory \\
\hline
\end{tabular}

Tab. 2. Assessment of microclimate conditions in long-walls

Tab. 2. Wyniki oceny warunków mikroklimatu na ścianach

\begin{tabular}{|c|c|c|c|c|c|c|}
\hline \multirow{2}{*}{ No } & \multirow{2}{*}{ Long-wall name } & \multirow{2}{*}{$\begin{array}{l}\text { Temperature } \\
\left({ }^{\circ} \mathrm{C}\right)\end{array}$} & \multirow{2}{*}{$\begin{array}{c}\text { Humidity } \\
(\%)\end{array}$} & \multirow{2}{*}{$\begin{array}{l}\text { Wind speed } \\
(\mathrm{m} / \mathrm{s})\end{array}$} & \multicolumn{2}{|c|}{$\begin{array}{l}\text { Assess according to the standard of } \\
\text { Vietnam }\end{array}$} \\
\hline & & & & & Standard, ${ }^{\circ} \mathrm{C}$ & Assess \\
\hline 1 & Long-wall level -40/-35 V8 & 28.0 & 85 & 1,0 & $<30$ & Reached \\
\hline 2 & Long-wall level -10 V13 & 28.0 & 60 & 0,9 & $<30$ & Reached \\
\hline 3 & Long-wall level -20 V13 & 28.0 & 60 & 0,9 & $<30$ & Reached \\
\hline
\end{tabular}

Tab. 3. Assessment of $\mathrm{CO}_{2}, \mathrm{CH}_{4}$ and $\mathrm{CO}$ concentrations in long-walls

Tab. 3. Wynki ocena stężeń $\mathrm{CO}_{2}, \mathrm{CH}_{4}$ i $\mathrm{CO}$ na ścianach

\begin{tabular}{|c|l|c|c|c|c|}
\hline No & \multicolumn{1}{|c|}{ Measuring point } & $\begin{array}{c}\text { Concentration } \\
\mathrm{CO}_{2}, \%\end{array}$ & $\begin{array}{c}\text { Concentration } \\
\mathrm{CH}_{4}, \%\end{array}$ & $\begin{array}{c}\text { Concentration } \\
\mathrm{CO}, \%\end{array}$ & Assess \\
\hline 1 & Longwall level -40/-35 V8 & 0.2 & 0.0 & 0.0 & Reached \\
\hline 2 & Longwall level -10 V13 & 0.3 & 0.0 & 0.0 & Reached \\
\hline 3 & Longwall level -20 V13 & 0.3 & 0.0 & 0.0 & Reached \\
\hline
\end{tabular}

Through the survey of the mine ventilation network and the network of tunnels lines, it shows that most of the basic construction tunnels lines are dug in stone ensuring quality such as shape, support frame, cross-section compared to the original. As for the tunnels lines that are going to be digged in coal, after the use time, they are affected by the pressure of mines changing the area and shape of the tunnels, but not significantly.

b. Assess the ventilation situation of the longwall

- The direction of the wind going in the longwall: Long-wall LC - $40 /-35 \mathrm{~V} 8$ is ventilated in accordance with regulations, the direction of the wind going in the longwall is from the bottom up.

The tilted longwall: LC-NN/-10V13 and LC-NN/-20V13 are ventilated by local fans JBT- $11 \mathrm{~kW}$, the clean wind is pushed through the duct into the oven, the direction of wind coming out from the longwall oven from bottom to top in accordance with the rules of safety.

- Regarding the flow of wind through the longwalls: Calculated results and the actual wind volume measured in the longwalls are shown in Table 1.

Out of the 3 long-walls in the mining area, at the time of survey of mine ventilation network, there are 3 operating longwalls. The amount of wind passing through the longwalls is sufficient as required as calculated.

- Regarding microclimate: The results of measurement of some key parameters of microclimate conditions in the longwalls (wind speed, temperature and humidity) as well as the evaluation of microclimate conditions according to Vietnamese standards, are listed in Table 2.

According to the comfortable microclimate standard of Vietnam, the microclimate conditions in the 3 longwalls are guaranteed to be comfortable (with the temperature $<30^{\circ} \mathrm{C}$. However, the humidity in the longwall seams 8 is still high $(85 \%)$. The humidity in the 2 long-walls is tilted at a moisture content of seams 13 reached.

- Assessing the contentcentration of gases: $\mathrm{CO}, \mathrm{CO}_{2}$ and $\mathrm{CH}_{4}$ gases in the longwalls: The survey results show the concentration of gases as in Table 3. Assessment of toxic, harmful and explosive flammable gases concentrations are at a guaranteed level and fluctuate within the permissible standard limits.

c. Assessment of ventilation situation of the prepared tunnel faces

In 2019 , the mine must mobilize up to 10 tunnel faces. Characteristics of the faces are shown in Table 4.

- Evaluation of ventilation method: Ventilation method when using the prepared tunnel faces, is a push ventilation method (using fans and pipes). This is a completely consistent and guaranteed method.

- Evaluation of the windpipe: At the current mine, the windpipe is a soft windpipe, made of rubber-coated canvas with a diameter of $600 \mathrm{~mm}, 700 \mathrm{~mm}$. The length of each duct section is 20 or $25 \mathrm{~m}$. This type of material is also suitable for the conditions of Hon Gai coal mine as well as Vietnamese mines.

This type of duct is very reasonable because it is suitable for the area of the dug tunnels, the length of each tunnel, as well as the type of fan used. In general, the quality of the air ducts used is satisfactory.

- About the working ability of the local fans: The fans used to ventilate the faces are mostly new types, common in Quang Ninh coal area manufactured by China. They are explosion-proof, single-stage fans with each engine output of $11 \mathrm{~kW}$ to $22 \mathrm{~kW}$. 
Tab. 4. Characteristics of the prepared tunnel faces

Tab. 4. Charakterystyka przygotowanych ścian tunelu

\begin{tabular}{|c|l|c|c|c|}
\hline No & \multicolumn{1}{|c|}{ Name of the prepared tunnel lines } & Anti-material & $\begin{array}{c}\text { Area of use } \\
\left(\mathrm{m}^{2}\right)\end{array}$ & $\begin{array}{c}\text { Ventilation } \\
\text { length }(\mathrm{m})\end{array}$ \\
\hline 1 & Transport inclined tunnel level -70/-50V8 & Door made of iron & 8.4 & 90 \\
\hline 2 & Tunnel vertical seams level -100 LC I-11-1V11 & Door made of iron & 9.4 & 100 \\
\hline 3 & Tunnel vertical seams level -85V11 & Door made of iron & 8.4 & 95 \\
\hline 4 & Tunnel vertical seams level +20 Block 4V13 & Door made of iron & 9.4 & 70 \\
\hline 5 & The coal tunnel is inclined to level -100/-80 V12 $\div$ V13 & Door made of iron & 9.4 & 120 \\
\hline 6 & $\begin{array}{l}\text { Ventilated inclined coal tunnel level -160 - -50 V.12 } \\
\text { area I }\end{array}$ & Door made of iron & 9.4 & 120 \\
\hline 7 & Tunnel vertical seams level of longwall I-12-2 & Door made of iron & 9.4 & 95 \\
\hline 8 & Tunnel vertical horizontal stone seam level -160V12 & Door made of iron & 9.4 & 90 \\
\hline 9 & $\begin{array}{l}\text { Ventilated inclined coal tunnel level +20 longwall I-12- } \\
\text { 2a }\end{array}$ & Door made of iron & 9.4 & 150 \\
\hline 10 & $\begin{array}{l}\text { Ventilated inclined coal tunnel level +20 } \div-50 \text { V.12 } \\
\text { arra I }\end{array}$ & Door made of iron & 9.4 & 100 \\
\hline
\end{tabular}

Tab. 5. Measurement results of toxic gases in tunnels faces

Tab. 5. Wyniki pomiarów toksycznych gazów w kopalni

\begin{tabular}{|c|c|c|c|c|c|}
\hline \multirow[b]{2}{*}{ No } & \multirow[b]{2}{*}{ Tunnels faces } & \multicolumn{3}{|c|}{ Results of gas concentration } & \multirow[b]{2}{*}{ Assess } \\
\hline & & $\begin{array}{l}\mathrm{CH}_{4} \\
(\%)\end{array}$ & $\begin{array}{l}\mathrm{CO}_{2} \\
(\%)\end{array}$ & $\mathrm{CO}(\%)$ & \\
\hline 1 & Transport inclined tunnel level -70/-50V8 & 0.0 & 0,3 & 0.0 & Reached \\
\hline 2 & Tunnel vertical seams level -100 LC I-11-1V11 & 0.0 & 0,2 & 0.0 & Reached \\
\hline 3 & Tunnel vertical seams level -85V11 & 0.0 & 0,3 & 0.0 & Reached \\
\hline 4 & Tunnel vertical seams level +20 Block $4 \mathrm{~V} 13$ & 0.0 & 0,2 & 0.0 & Reached \\
\hline 5 & The coal tunnel is inclined to level $-100 /-80 \mathrm{~V} 12 \div \mathrm{V} 13$ & 0.0 & 0,2 & 0.0 & Reached \\
\hline 6 & Ventilated inclined coal tunnel level $-160 \div-50 \mathrm{~V} .12$ area I & 0.0 & 0,15 & 0.0 & Reached \\
\hline 7 & Tunnel vertical seams level of longwall I-12-2 & 0.0 & 0,3 & 0.0 & Reached \\
\hline 8 & Tunnel vertical and horizontal stone seam level -160V12 & 0.0 & 0,3 & 0.0 & Reached \\
\hline 9 & Ventilated inclined coal tunnel level +20 longwall I-12-2a & 0.0 & 0,2 & 0.0 & Reached \\
\hline 10 & Ventilated inclined coal tunnel level $+20 \div-50 \mathrm{~V} .12$ area I & 0.0 & 0,3 & 0.0 & Reached \\
\hline
\end{tabular}

The local fans used at the mine are all qualified and consistent with the characteristics of the mine's tunnels. Respond well to the ventilation for the tunnel faces prepared as planned.

- Ventilation quality of prepared tunnel faces: In addition to the actual airflow surveyed to the prepared tunnel faces, we also determine the concentration of toxic (CO), harmful $\left(\mathrm{CO}_{2}\right)$ and explosive flammable $\left(\mathrm{CH}_{4}\right)$ gases. In faces as well as environmental parameters (temperature, the humidity of the air). These are important factors that evaluate the quality of ventilation in the preparation tunnel. Survey results measured the content of hazardous gases, as shown in Table 5 and the results of microclimate conditions, as shown in Table 6.

Assessment of ventilation quality for preparation tunnel faces:

Content of toxic, harmful and explosive flammable gases: All within the permitted maximum limit (almost negligible, especially methane without). This shows that the ventilation of the tunnel faces is prepared according to safety regulations, ensuring good ventilation quality.

Microclimate: In 10 tunnel faces, it shows that the temperature in all of the tunnel faces is within the permitted norm and is smaller than the maximum Vietnamese standard value allowed $<30$ oC (Tran Xuan Ha, Nguyen Cao Khai et al., 2012). d. Evaluation of ventilation structures

- Regarding the main fans station: Giap Khau mine has 3 main fan stations all using FBDCZ-4-No13/2x22kW fans, made in China: The main fan station No.1, positioned at the mouth of the tunnel level +36 ; The main fan station No.2, positioned at the mouth of the tunnel level +45 ; The main fan station No.3, positioned at the mouth of the tunnel level +130 . The fan stations are designed in a semi-permanent form, and the fan mouth is directly connected to the wind tunnel, the fan is located outdoors. In Fig. 5, we introduce the general shape of semi-permanent fan stations in Giap Khau.

All three fan stations do not have a reversing system, the wind reversal is done by reversing the motor rotation (reversing the rotation of the fan shaft), but this situation does not affect the work quality of the fan station.

The main fans of all 3 fan stations are built with concrete, ensuring technical requirements.

The largest of all three fan stations is that there is no window in the fan slot for measuring flow and lowering the fan pressure. Therefore, these parameters must be measured in the tunnel line. Therefore, measurement results will have certain errors.

- Quality of air vents door: Through surveying and measuring the air vents of the mine, the results are as shown in Table 7. 
Tab. 6. Results of measuring microclimate conditions in tunnels faces

Tab. 6. Wyniki pomiarów warunków mikroklimatu na ścianach

\begin{tabular}{|c|l|c|c|c|c|}
\hline \multirow{2}{*}{ No } & \multicolumn{1}{|c|}{ Tunnels faces } & \multicolumn{3}{c|}{ Microclimate parameters } & $\begin{array}{c}\text { Assess according to the } \\
\text { standard of Vietnam }\end{array}$ \\
\cline { 3 - 6 } & & \multicolumn{1}{|c|}{$\begin{array}{c}\text { wind speed } \\
(\mathrm{m} / \mathrm{s})\end{array}$} & $\begin{array}{c}\text { Temperature } \\
\left({ }^{0} \mathrm{C}\right)\end{array}$ & $\begin{array}{c}\text { Humidity } \\
(\%)\end{array}$ & Reached \\
\hline 1 & Transport inclined tunnel level -70/-50V8 & 5 & 28 & 70 & Reached \\
\hline 2 & $\begin{array}{l}\text { Tunnel vertical seams level -100 LC I- } \\
11-1 \text { V11 }\end{array}$ & 5,2 & 27 & 65 & Reached \\
\hline 3 & Tunnel vertical seams level -85V11 & 5,4 & 28 & 60 & Reached \\
\hline 4 & $\begin{array}{l}\text { Tunnel vertical seams level +20 Block } \\
4 \text { V13 }\end{array}$ & 5,1 & 28 & 70 & Reached \\
\hline 5 & $\begin{array}{l}\text { The coal tunnel is inclined to level -100/- } \\
80 \text { V12 } \div \text { V13 }\end{array}$ & 5,7 & 28 & 70 & Reached \\
\hline 6 & $\begin{array}{l}\text { Ventilated inclined coal tunnel level - } \\
160 \div-50 \text { V.12 area I }\end{array}$ & 5,2 & 27,5 & 65 & Reached \\
\hline 7 & $\begin{array}{l}\text { Tunnel vertical seams level of longwall I- } \\
12-2\end{array}$ & 5,5 & 29 & 80 & Reached \\
\hline 8 & $\begin{array}{l}\text { Tunnel vertical horizontal stone seam } \\
\text { level -160V12 }\end{array}$ & 4,7 & 28 & 60 & Reached \\
\hline 9 & $\begin{array}{l}\text { Ventilated inclined coal tunnel level +20 } \\
\text { long-wall I-12-2a }\end{array}$ & 5,5 & 28 & 65 & Reached \\
\hline 10 & $\begin{array}{l}\text { Ventilated inclined coal tunnel level +20 } \\
\div-50 \text { V.12 arra I }\end{array}$ & 7,8 & 28 & 65 & \\
\hline
\end{tabular}

Tab. 7. Results of the survey of air inlets

Tab.7. Wyniki przeglądu wlotów powietrza

\begin{tabular}{|c|c|l|l|c|}
\hline No & $\begin{array}{c}\text { Type of } \\
\text { construction }\end{array}$ & \multicolumn{1}{|c|}{ Location } & \multicolumn{1}{|c|}{ Status, characteristics, texture } & $\begin{array}{c}\text { Leak airflow, } \\
\mathrm{m}^{3} / \mathrm{s}\end{array}$ \\
\hline 1 & $\begin{array}{c}\text { Wind blocker } \\
\text { door }\end{array}$ & Oven door level +36 & $\begin{array}{l}\text { Door made of iron, 2 wing opens push 2 sides, } \\
\text { the roaring tunnel gap is even greater. }\end{array}$ & 2,6 \\
\hline 2 & $\begin{array}{c}\text { Wind blocker } \\
\text { door }\end{array}$ & Oven door level +45 & $\begin{array}{l}\text { Door made of iron, 2 wing opens push 2 sides, } \\
\text { the roaring tunnel gap is even greater. }\end{array}$ & 3,1 \\
\hline 3 & $\begin{array}{c}\text { Wind blocker } \\
\text { door }\end{array}$ & Oven door level +130 & $\begin{array}{l}\text { Door made of iron, 2 wing opens push 2 sides, } \\
\text { the roaring tunnel gap is even greater. }\end{array}$ & 3,0 \\
\hline 4 & $\begin{array}{c}\text { Wind blocker } \\
\text { door }\end{array}$ & $\begin{array}{l}\text { Tunnel across the seams } \\
\text { level+18 }\end{array}$ & $\begin{array}{l}\text { 02 doors } 80 \mathrm{~m} \text { apart, made of steel material, } 2 \\
\text { wings open }>90^{\circ}, \text { brick surrounding the frame }\end{array}$ & 1,7 \\
\hline 5 & $\begin{array}{c}\text { Wind blocker } \\
\text { door }\end{array}$ & $\begin{array}{l}\text { Connector tunnel level } \\
+18\end{array}$ & $\begin{array}{l}\text { 02 doors } 60 \mathrm{~m} \text { apart, made of steel material, 2 } \\
\text { wings open }>90^{\circ}, \text { brick surrounding the frame }\end{array}$ & 2,8 \\
\hline 6 & $\begin{array}{c}\text { Wind blocker } \\
\text { door }\end{array}$ & $\begin{array}{l}\text { Tunnel across the seams } \\
\text { level }-50\end{array}$ & $\begin{array}{l}\text { 02 doors } 80 \mathrm{~m} \text { apart, made of steel material, } 2 \\
\text { wings open }>90^{\circ}, \text { brick surrounding the frame }\end{array}$ & 4,0 \\
\hline
\end{tabular}

Three doors block the wind at the tunnel gates of Level level +36 , level +45 and level +130 Giap Khau mines area are designed as double doors, about $80 \mathrm{~m}$ apart, the door is made of iron, the walls are built with cement mortar bricks, the doors are opened and closed side. The door quality is still good, but there is still a big wind leak, due to the large gap (especially the gap in the lower part of the tunnel floor contact between the door and the gutter and transport rails, the gap is up to $3 \div 5 \mathrm{~cm}$ ). Here the pressure difference is not large, but the wind loss is still relatively large to $2.6 \div 3.1 \mathrm{~m}^{3} / \mathrm{s}$, exceeding the permissible standards.

The air inlets in the tunnel branchs or each logging area are mostly made of wood or iron frames, but the wings are made of assembled wood panels. Most of these doors do not guarantee tightness, so the amount of wind leakage is relatively large.

The wind adjustment windows are built to ensure quality and are selected in a reasonable position so as not to affect much to other tasks such as travel and transportation.
- The quality of barrier walls: All windbreak walls of Giap Khau area are designed and built with cement mortar bricks, ensuring the construction quality standards and meeting the allowed wind leakage standards.

e. Assessing the status of the ventilated tunnel lines in the mine

Through the survey of the quality of the mines' crossseams, the cross-section is stable, almost no subsidence due to pressure. There are no obstructions in the kiln that obstruct the movement of vehicles and ventilation in the mine. The tunnel lines along the seams in the quarry almost meet the requirements.

f. Evaluate the working mode of the main fans

- FBDCZ-4-No13/2x22kW fans (door level +36): Fan operating mode as shown in Table 8.

- FBDCZ-4-No13/2x22kW fan (door level +45): Fan operating mode as shown in Table 9.

- FBDCZ-4-No13/2x22kW fan (door level +130): Fan operating mode as shown in Table 10. 


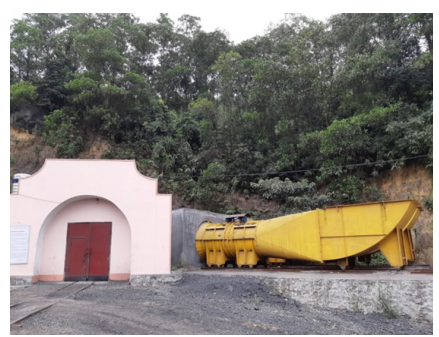

Fig. 5. The shape of the main fans stations in Giap Khau mine Rys. 5. Głównych stacje wentylatorów w kopalni Giap Khau

Tab. 8. FBDCZ-4-No13/2x22 fan operating mode (+36 level) Tab. 8. Tryb pracy wentylatora FBDCZ-4-No13 / 2x22 (poziom +36)

\begin{tabular}{|c|l|c|c|}
\hline No & \multicolumn{1}{|c|}{ The working parameters of the fan } & Current working mode & $\begin{array}{c}\text { Working mode as required } \\
\text { (calculate) }\end{array}$ \\
\hline 1 & Tilt angle of the wing $(\theta)$, angle & $-2,5^{0}$ & 0 \\
\hline 2 & $\mathrm{Q}, \mathrm{m}^{3} / \mathrm{s}$ & 18,6 & 20,9 \\
\hline 3 & $\mathrm{~h}, \mathrm{mmH}_{2} \mathrm{O}$ & 106 & 116 \\
\hline 4 & $\mathrm{n}, \%$ & 78 & 78 \\
\hline
\end{tabular}

Tab. 9. FBDCZ-4-No13/2x22 fan operating mode (+45 level)

Tab. 9. Tryb pracy wentylatora FBDCZ-4-N013 (poziom +45

\begin{tabular}{|c|l|c|c|}
\hline No & \multicolumn{1}{|c|}{ The working parameters of the fan } & Current working mode & $\begin{array}{c}\text { Working mode as required } \\
\text { (calculate) }\end{array}$ \\
\hline 1 & Tilt angle of the wing $(\theta)$, angle & -5 & $-2,5$ \\
\hline 2 & $\mathrm{Q}, \mathrm{m}^{3} / \mathrm{s}$ & 16,7 & 20 \\
\hline 3 & $\mathrm{~h}, \mathrm{mmH}_{2} \mathrm{O}$ & 93,3 & 106,8 \\
\hline 4 & $\eta, \%$ & 74 & 75 \\
\hline
\end{tabular}

From the data in Table 8, it is found that the airflow generated by the fan is insufficient compared to the requirement of $1.06 \mathrm{~m} 3 / \mathrm{s}$ (about $5.39 \%$ ). Table 9 shows that the generated fan airflow is insufficient compared to the required $2.76 \mathrm{~m} 3 / \mathrm{s}$ (about 14.18\%) and Table 10 shows the insufficient fan airflow compared to the requirement of $0.46 \mathrm{~m}^{3} / \mathrm{s}$ (approx. 2.92\%). Thus, the current working mode of the main fans is insufficient compared to the requirements as designed.

All 3 fans at 3 fan stations of the mining area still have reserve capacity: FBDCZ-4-No13/2x22 fan at the door is level +36 , only working at the corner of wing installation $0 \mathrm{o}$; FBDCZ-4-No13/2x22kW fan is at the upper tunnel door level +45 , just working at the corner of wing $2.5^{\circ}$ and FBDCZ-4-No13/2x22kW fan is at the top of the tunnel door level +130 , just working at the corner $-5^{\circ}$ wing mount. However, in fact, the main fan of FBCZ-4-No13/2×22 type is a small-capacity fan, although there is still a spare angle of the wings, due to the low pressure of the mines is relatively large, the reserve capacity is no longer a lot of.

\section{Solutions to improve mine ventilation efficiency}

\subsection{Technical solutions should be implemented to complete} the ventilation system of the mine

To complete the mine ventilation system and improve ventilation efficiency, the following measures must be applied:

1 - Regularly check and check the airflow into the longwall faces and prepare tunnel faces to meet the requirements.

2 - The longwall LC -40/-35V8 is a long oven; currently the ventilation conditions are relatively good assurance: the air temperature is still less than 300 (280C), but the air humidity of this longwall is relatively high (85\%), this is in the winter if the weather changes in the humid season or in the summer, the humidity may increase, and the likelihood of it is relatively hot when the humidity increases to $90 \%$. It is necessary to calculate and adjust to add clean wind to the longwall to create a better microclimate.

3 - For the ventilation of the tunnel faces, it is necessary to pay special attention to the capacity of the fans used and the quality of the ducts, duct quality, to reduce the degree of wind damage on piping and especially keep a reasonable distance of the duct mouth to the tunnel face, ensuring the space near the tunnel face with the appropriate wind speed, creating the best microclimate.

4 - At fan stations, it is necessary to process additional doors to check the working mode of the main fan at the fan slot. At each fan station, the inspection door is arranged in the fan groove and about $10-15 \mathrm{~m}$ from the fan with a size of $300 \mathrm{~mm} \times 300 \mathrm{~mm}$. The inspection door has a closed-door when the fan is working when it is necessary to measure the fan's working capacity; it is opened.

5 - The determination of the common mine ventilation pressure of the mine, is usually carried out by actual survey measurements, or by theoretical calculations. But these values are generally less than the real value. Therefore, the determination of the reasonable working mode of the fan will be inaccurate, on the other hand, the characteristic fan lines are those built on the basis of the general resistance condition that is the sample resistance at the home factory. Therefore, these fea- 
Tab. 10. FBDCZ-4-No13/2x22 fan operating mode (+130 level)

Tab. 10. Tryb pracy wentylatora FBDCZ-4-N013 przy +130

\begin{tabular}{|c|l|c|c|}
\hline No & \multicolumn{1}{|c|}{ The working parameters of the fan } & Current working mode & $\begin{array}{c}\text { Working mode as required } \\
\text { (calculate) }\end{array}$ \\
\hline 1 & Tilt angle of the wing $(\theta)$, angle & -5 & -5 \\
\hline 2 & $\mathrm{Q}, \mathrm{m}^{3} / \mathrm{s}$ & 15,3 & 16,2 \\
\hline 3 & $\mathrm{~h}, \mathrm{mmH}_{2} \mathrm{O}$ & 103 & 88,2 \\
\hline 4 & $\mathrm{n}, \%$ & 76 & 75 \\
\hline
\end{tabular}

ture lines are only theoretical characteristic lines. Therefore, to ensure the accuracy, during the operation of the fan station, it is necessary to periodically check the construction of the actual characteristics of the fan station (Marius Cornel Șuvar, Constantin Lupu, Victor Arad, Doru Cioclea, Vlad Mihai Păsculescu, Nelu Mija, 2014).

6 - The mine's air doors are all designed and manufactured with walls made of cement mortar and iron wings, ensuring the required stability. However, the air doors have not designed a closed structure to prevent wind leakage when reversing the wind. Therefore, it is necessary to design more so that the door has a closed mechanism when reversing the wind.

7 - Currently, the mine has invested in installing ventilation safety management system at the centre and has a monitoring and updating screen. Therefore, the mine may consider investing in positioning equipment to control and monitor the management of officials who conduct wind and gas survey measurements in the field when reversing (M. Shriwas and F. Calizaya, 2018; M.A. Moridi et al., 2015; A.J.H. Nel et al., 2018).

\subsection{The solution when the mine area increase production and bring project below level -50 into exploitation}

To the period of 2021, mine area Giap Khau field will increase the exploitation output to 400,000 tons/year and then by 2024 , the lower level project from -160 to -50 will be put into operation, which will increase the output to 500,000 tons/year. The increase in mining output will lead to increased mine ventilation capacity. Plan to increase mining output to 400,000 tons/year, the mine must mobilize 7 longwall (mainly type horizontal tilt longwall) and 21 tunnel faces (Hon Gai coal Company - Vietnam, 2019b; Vietnam coal - minerals industries holding corporation limited, 2019b). The schematic diagram of the ventilation tunnel system is shown in Fig. 6 .

When the mine increases its output, especially in the period of putting projects below -50 in operation, the solutions to improve ventilation efficiency are:

1. Fully implementing the solutions as proposed for the current period.

2. Investing in replacement of main wind fan with suitable large capacity

The calculation of ventilation and the selection of the main fan for the area when increasing output is done with the following results:

a. Mine ventilation calculation results

The overall wind volume of the mine is determined by the following formula (Tran Xuan Ha, Nguyen Cao Khai et al., 2014):
$Q_{m}=1,1\left(k_{s} \sum Q_{l c}+\sum Q_{c b}+\sum Q_{h t}+\sum Q_{r g}\right)_{,} m^{3 / s}$

Plug the number into the formula to get Qm:

$\mathrm{Q}_{\mathrm{m}}=1,1(1,1 \times 22,4+26,4+1,2+11,74)=70,4 \mathrm{~m}^{3} / \mathrm{s}$

With the required airflow for the mine area is $70.4 \mathrm{~m} 3 / \mathrm{s}$, the existing three main wind fans of the site cannot meet the requirements. Therefore, the Company must invest in building a new fan station with the appropriate capacity to ensure ventilation.

Based on the assessment of the current status and development orientation of the mine, we propose a plan to replace the main fan station at the tunnel gate-level +36 with FBDCZ-8-No23/2x200kW fan. And the two main fan stations at the doors of the tunnels level +45 , and level +130 remain FBDCZ-4-No13/2x22kW.

Calculate the flow of mine wind to the three main fan stations as follows:

- Fan 1 level +36 (FBDCZ-4-No23/2x200kW): Qm1 = 38,1 m³ $/ \mathrm{s}$; - Fan 1 level +45 (FBDCZ-4-No13/2x22kW): Qm2 = 15,4 m³/s; - Fan 1 level +130 (FBDCZ-4-No13/2x22kW): Qm3 = 16,9 m³/s;

Ventilation pressure of the corresponding airflows to the three main fan stations as follows:

- Ventilation pressure of the fan FBCDZ-4-No23 at door level +36 work as follows: $\mathrm{h} 1=305,8 \mathrm{mmH} 2 \mathrm{O}$

- Ventilation pressure of the fan FBCDZ-4-No13 at door level +45 work as follows: $\mathrm{h} 2=69,6 \mathrm{mmH} 2 \mathrm{O}$;

- Ventilation pressure of the fan FBCDZ-4-No13 at door level +130 work as follows: $\mathrm{h} 3=103,1 \mathrm{mmH} 2 \mathrm{O}$;

b. Optimal working mode of the main fans

The calculation to determine the working mode of the main fans is calculated based on the general regulations and using the calculation method to determine the working mode of the fans by the graph method (Nguyen Cao Khai and others, 2015). The result of determining the working mode of main fans is as follows:

- Fan station No.1: Door of tunnel the level +36 (FBDCZ-8-No23), the reasonable working point of the fan is Dct1 as shown in Fig. 7. With parameters:

$\mathrm{Q}_{\mathrm{ct} 1}=41.1 \mathrm{~m}^{3} / \mathrm{s}$;

$\mathrm{h}_{\mathrm{ct} 1}=322.2 \mathrm{mmH}_{2} \mathrm{O}$;

$\mathrm{n}=740 \mathrm{r} / \mathrm{m} ; \theta=2.50$;

$\eta_{1}=0.77$.

- Fan station No.2: Door of tunnel the level +45 (FBDCZ-4-No13), the reasonable working point of the fan is Dct2 as shown in Fig. 8. With parameters:

$\mathrm{Q}_{\mathrm{ct} 2}=17.8 \mathrm{~m} 3 / \mathrm{s}$

$\mathrm{h}_{\mathrm{ct} 2}=88.1 \mathrm{mmH}_{2} \mathrm{O}$; 


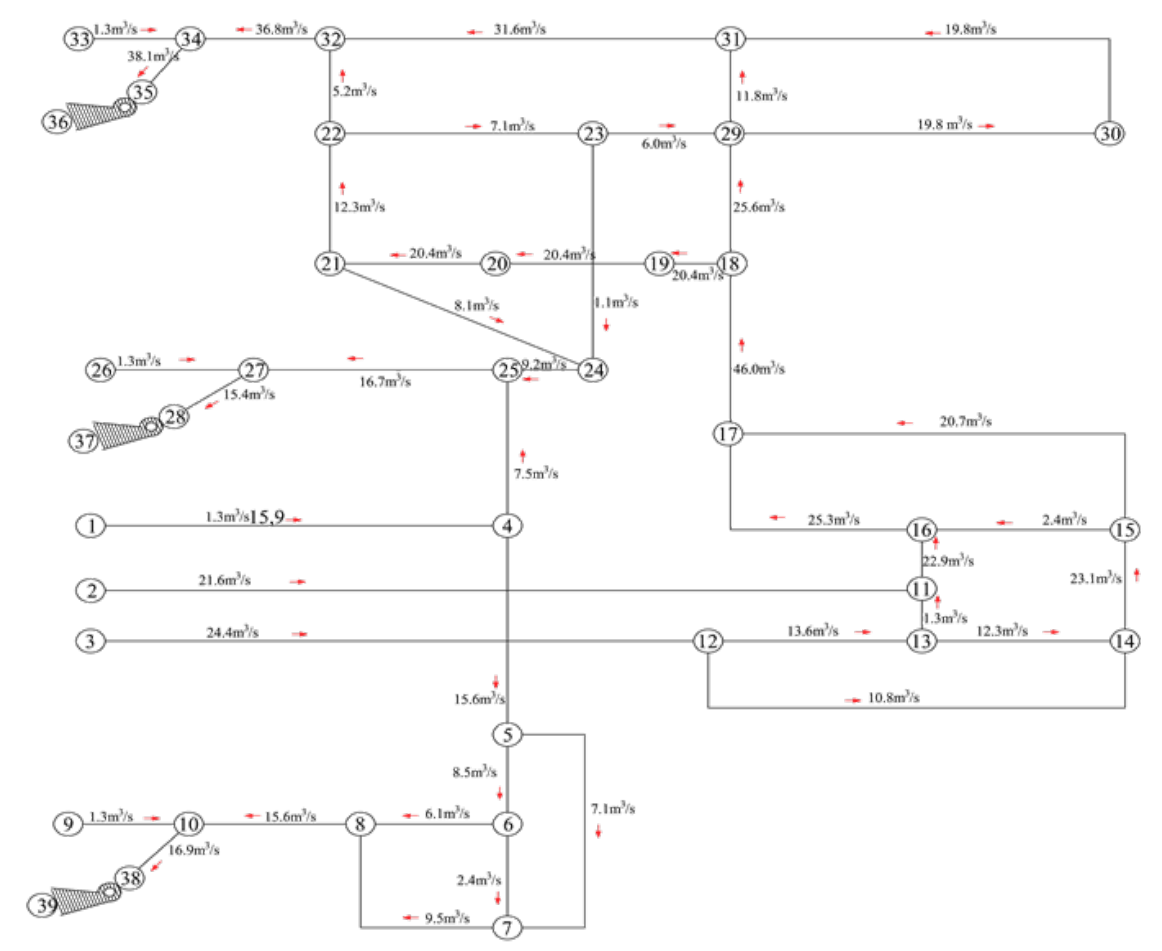

Fig. 6. The ventilation diagram of Giap Khau mine area in the period of increasing exploitation output to 400,000 tons/year Rys. 6. Schemat wentylacji obszaru kopalni Giap Khau w okresie zwiększania wydobycia do 400 tys. ton/rok

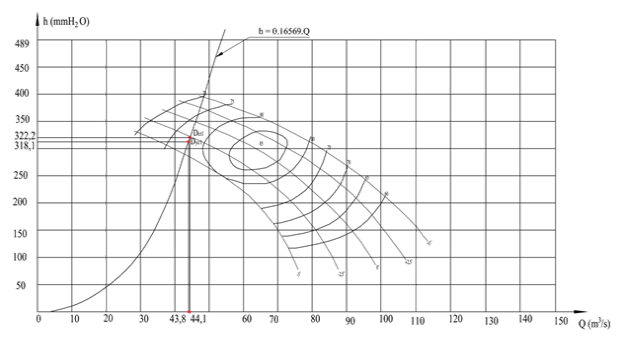

Fig. 7. Graph of determining the working mode of the fan FBDCZ-4-No23 at the door of tunnel the level +36 when increasing production to 400,000 tons/year Rys. 7. Wykres wyznaczenia trybu pracy wentylatora FBDCZ-4-No23 na wejściu do tunelu na poziomie +36 przy zwiększaniu produkcji do 400000 ton / rok

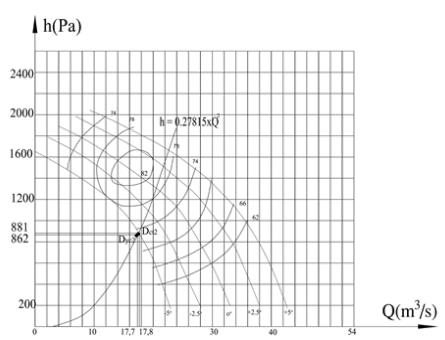

Fig. 8. Graph of determining the working mode of the fan FBDCZ-4-No13 at the door of tunnel the level +45 when increasing production to 400,000 tons/year Rys. 8. Wykres wyznaczenia trybu pracy wentylatora FBDCZ-4-No13 na wejściu do tunelu na poziomie +45 przy zwiększaniu produkcji do 400000 ton / rok

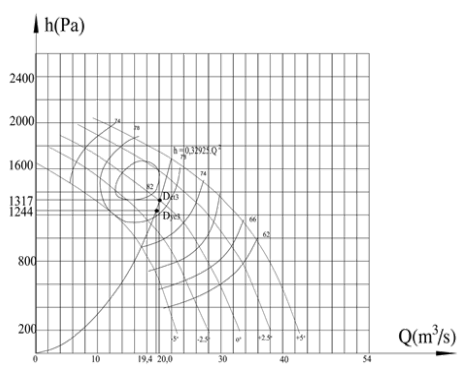

Fig. 9. Graph of determining the working mode of the fan FBDCZ-4-No13 at the door of tunnel the level +130 when increasing production to 400,000 tons/year Rys. 9. Wykres wyznaczenia trybu pracy wentylatora FBDCZ-4-No13 na wejściu do tunelu na poziomie +130 przy zwiększaniu produkcji do 400000 ton / rok 


$$
\begin{aligned}
& \mathrm{n}=740 \mathrm{r} / \mathrm{m} ; \\
& \theta=-50 ; \\
& \eta_{2}=0.73 .
\end{aligned}
$$

- Fan station No.3: Door of tunnel the level +130 (FBD-

CZ-4-No13), the reasonable working point of the fan is Dct3 as shown in Fig. 9. With parameters:

$\mathrm{Q}_{\mathrm{ct} 3}=20.0 \mathrm{~m}^{3} / \mathrm{s}$

$\mathrm{h}_{\mathrm{ct} 3}=131.7 \mathrm{mmH}_{2} \mathrm{O}$;

$\mathrm{n}=740 \mathrm{r} / \mathrm{m}$;

$\theta=-00$

$\eta_{3}=0.80$.

\section{Conclusion}

Currently, basically, the ventilation system of Giap Khau mine area is guarantee upon request. However, in order to further improve the efficiency of mine ventilation, Hon Gai coal Company needs to implement the solutions that we have proposed. Especially in the period to come when the mine area has to increase the exploitation output, as well as when putting project below -50 in operation, it is necessary to add a solution to replace the main fan station with a large capacity suitable, to ensure ventilation for mine area as required.

With the results of research and ventilation calculations for Giap Khau mine area, the solutions we have proposed are practical. These results will help the mine to perform effectively in the current period, and also help the mine to have a long-term orientation for investment in mine ventilation. Ensuring to improve the efficiency of mine ventilation, improving working environment conditions of workers, maintaining and ensuring good work safety, contributing to reducing costs for mine ventilation in particular, as well as lower overall costs and investment in mining. 


\section{Literature - References}

1. Tran Xuan Ha, Nguyen Cao Khai et al. (2012). Occupational safety and sanitation in pit mining. Science and Technology Publishing House, Hanoi 2012.

2. Tran Xuan Ha, Nguyen Cao Khai et al. (2014). Mine ventilation curriculum. Science and Technology Publishing House, Hanoi, 357tr.

3. Nguyen Cao Khai and others (2015). Determine the reasonable working regime of the main fan stations to improve the ventilation efficiency for some coal mines in Quang Ninh region. Journal of mining industry, No. 2-2015, Hanoi, Tr.25-29.

4. Nguyen Cao Khai, Nguyen Van Thinh, Nguyen Van Quang (2019). Assessing the current status of underground mine ventilation system in ThanhCong-CaoThang area, HonGai coal company, QuangNinh region, Vietnam. Journal of the Polish Mineral Engineering Society. Pp.44-50.

5. Nguyen Cao Khai et al. (2019). Inspection of wind network in Giap Khau area mine, Hon Gai coal company in 2019. Summary report of the project, Ha Nọi University of Mining and Geology, pp.23- 50.

6. Nguyen Cao Khai (2019). Optimizing working regime of main fan in underground coal mines in Quang Ninh. Doctoral thesis in engineering, University of Mining and Geology, Hanoi 2019.

7. Vietnam coal - minerals industries holding corporation limited, (2019a). Production and ventilation plans for affiliated companies in 2019. Episode 10, Pp. 1 - 62.

8. Vietnam coal - minerals industries holding corporation limited, (2019b). Production and ventilation plans for affiliated companies in 2020. Episode 10, Pp. 1 - 73.

9. Hon Gai coal Company - Vietnam (2019a). Plan for production and ventilation of Giap Khau mines area in 2019. Hon Gai coal Company-TKV, Tr.1-31.

10. Hon Gai coal Company - Vietnam (2019b). Plan for production and ventilation of Hon Gai coal Company in 2020 and planning directions to 2025. Hon Gai coal Company-TKV, Tr.1-53.

11. Babak G.A, K.P. Bocharov, AT Volokhiev (1982). Main ventilation fans for underground mining. - M: Nedra, - P 296.

12. Arnab Chatterjee, Lijun Zhang, Xiaohua Xia (2015). Analyze the quantity and test the different ventilation systems in the deep mine. Energy application. Episode 146, May 15, 2015, Pages 65-73.

13. Marius Cornel Șuvar, Constantin Lupu, Victor Arad, Doru Cioclea, Vlad Mihai Păsculescu, Nelu Mija (2014). Computerized simulatioon of mine ventilation networks for sustainable decision making process. Environmental Engineering and Management Journal. Gheorghe Asachi Technical University of Iasi, Romania. Pp. 1446-1451

14. M. Shriwas, F. Calizaya (2018). Automation in detection of recirculation in a booster fan ventilation network. Int J Min Sci Technol, 28 (2018), pp. 513-517.

15. M.A. Moridi, Y. Kawamura, M. Sharifzadeh, E.K. Chanda, M. Wagner, H. Jang, et a 1 (2015). Development of underground mine monitoring and communication system integrated ZigBee and GIS. Int J Min Sci Technol, 25 (2015), pp. 811-818.

16. A.J.H. Nel, J.C. Vosloo, M.J. Mathews (2018). Evaluating complex mine ventilation operational changes through simulations. J Energy South Africa, 29 (2018), pp. 22-32.

\section{Kopalni Giap Khau - Spółka Weglowa Hongai (Viet Nam)}

Zwiększająca się głębokość pokładów węgla w kopalniach podziemnych ogólnie mówiąc a szczególnie w kopalni Giap Khau i związany z niq wzrost temperatury pierwotnej górotworu sa powodem pogarszania się warunków mikro-klimatycznych pracy górników $i$ wystąpienia zagrożenia klimatycznego w przodkach górniczych. Wentylacja ma na celu rozrzedzenie stężeń gazów toksycznych, rozrzedzenie stężeń pyłów, usunięcie ich z kopalni oraz zapewnienie przyjemnych warunków mikroklimatycznych. W artykule, przedstawiono wyniki oceny aktualnego stanu wentylacji w kopalni Giap Khau i odpowiednie rozwiazania, które pozwalaja poprawić efektywność systemu wentylacji zwalczając zagrożenie klimatycznych kopalni.

Słowa kluczowe: wentylacja, wydajność wentylacji, kopalnia Giap Khau 